Historic, archived document

Do not assume content reflects current scientific knowledge, policies, or practices. 



\section{Just So.}

enember we are going to try and nube ever order sent out a staudingadvertise nent.

Pevery order, extra plants a seeds will be fown which we give tr as as appreciation of your patronage.

an you do better than order from us when rou consider that we warraut everything Were advertised?

1 Fere lies the secret of success : Pichardson: seeds given proper cultivation.

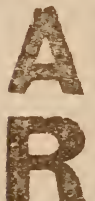

re you going to buy seeds or plants this season? If $s o$ select ouly tle best st)]d, hy Richardson.

ead the testimnnials in this book and ron will see that nur groods have been a niost pleasant surprise to those who have tried them.

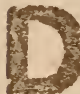

on't buy cheap seeds, for if rour crup fails there is no time to remedy it and your rear's work is lost.

emd to us and you will run no risk, for neither pains nor expense have been spared to get only superior goods.

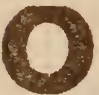

rder early so that vou may be sure of just what you want and take adrantage of our offers here sliown.

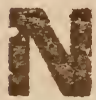

ow is the time to consider what vou are go ing to plant the coming season. Examine these pages carefully.

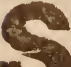

ome may sell clieaper, but depend on it, it nust come out of the goods and you are the loser.

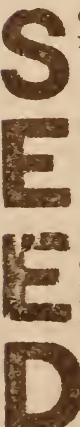

ee that we offer nothing which we caunot recommend 2 first class in every respect.

ntire satisfaction is guaranteed in every case, or we will cheerfully refund your money.

melishment in notling. We prefer to put Alir money into raising superior seeds and plants rather than into 2 chromo for 2 cata. logue.

are not trust to cheap seeds sold at the corner grocery. It is as easy to go to the Pist Office after your seeds as to the groce$r \mathrm{~V}$ store. A few days after sending your $\rightarrow r d e r$ to ins you will find them all safe in your Postoflice box.

nliciting your patronage for this seasou and knowing that we are sure of it in the future, we remain yours faithfully,

๑. M. RICHARDSON \& CO., CANTON, MAINE.

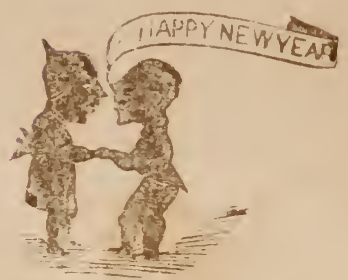

\section{Extra Plants.}

Thousands of plants have been raised and a large quantity of seeds to give away to our customers and every order of fift cents and over will contain some of theni. lle want all ot our customers to be pleased and we are noted for our liberality in putting in extras.

\section{Brugmansia.}

A rare and beautiful plant bearing pure white Howers often over one foot in length and seven inches in breadth. We will give a good strong plant of this to every one purchasing plants to the mount if one dollar. This offer holds good onl. while our stock of this plant lasts. Remember this is in addition to all other premiums.

\section{OUR POPULAR ONE DOLLAR COLLECTIONS.}

Any one of the collections named below will be sent on receipt of one dollar, securely packed and postpaid.

No. I.

6 Geraniums 60c., 6 Verthends 27c, 3 Petunias 30c., I Alutilon Ioc.. I Fuchsid loc. Total $\$ 1.45$

No. 2.

2 Chrysanthemums, 2 Fuchias, 2 Geraniums, , Calceolaria, a Achillea, 2 Begonias, 1 Dew Plant. Total $\$ 1.35$.

\section{No. 3.}

3 Carnatiuns, 3 Geraniums, 3 Begonias, 3 Salvias I Cal!a, I Ivy. Total \$1.50.

\section{No 4.}

2 Salvias, 2 Lantanas, 2 Geraniums, I Ivy Geran. ium, I Marguerite, I Bridal Rose, 2 Variegated Geiniums, I Farfugium, I Pylogpre Vine, 2 Pax. sy Geraniums. Total \$1.55.

\section{No. 5 .}

1 Cobea Scandens, 2 Chrysanthemuens, 2 Heli tropes, a Carations, 2 Geraniuns, 2 Fuchsias, Wax Plant. Total Si 30. 


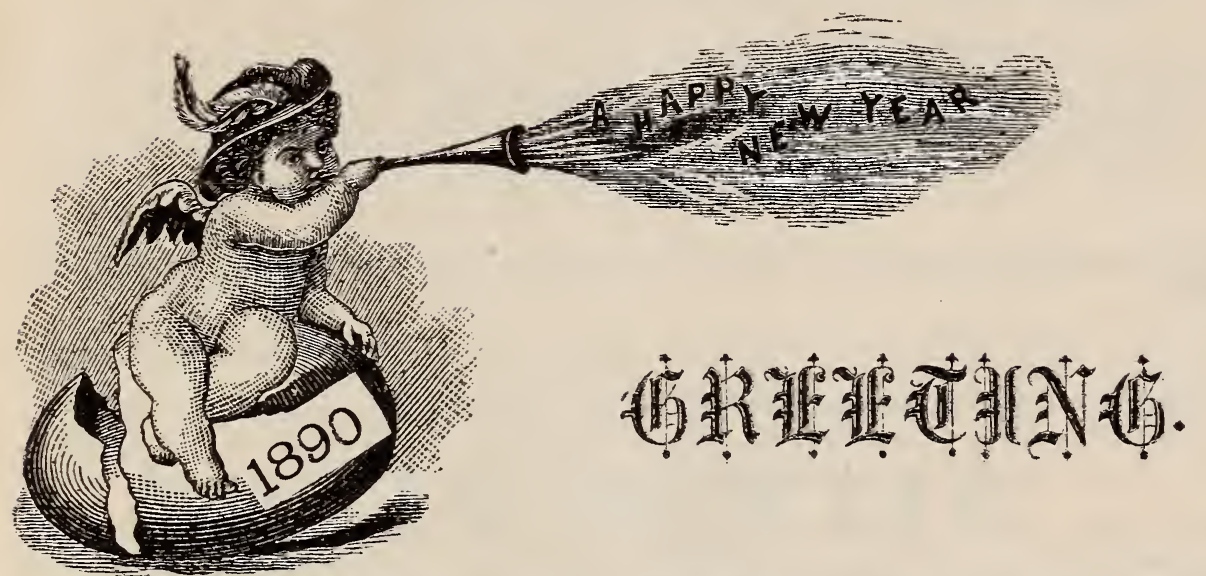

A nother year has come and gone: again we extend to our triends and customers a cordial greeting. From all parts of the country we hear nothing but praise for our plants wherever they have been tried.

Every year, as progress in civilization advances, more homes are made beautiful by the addition of flowers. What in more pleasing to the eye than a bed of choice geraniums or verbenas? Each flower is a wonder in itself. the mechanism of which no mecbanic can imitate, the color of which no artist can reproduce. Yet such may be had for a small outlay of time and money.

For the benefit of the thousands of homes which this little book will reach for the first time, we will say that our plants in vigor and hardiness are unsurpassed in this country; to those who have tried them we deem it unnecessary.

Thanking ar customers for their patronage in the past, and hoping for a contin. uance of the same this stason, we will close by wishing you all a happy and prosper. ous New Year.

\section{O. M. RICHARDSON \& CO.}

Remember our business is mostly by mail, being situated in a country place where there is little or no local trade; so that those who give us their orders will get nothing but the best, and not the learings, as is often the case when ordering from city firms where the best plants are picked out by loc:l customers who visit the greenhouse. Our weak point last season was the running short of many varieties. making it necessary to buy of other dealers to supply the demand. It caused some delay in fillng orders and the plants were inferior to those of our own growing. Our stock of plants for 1890 is immense, and we hope to fill all orders promptly. Our stock is grown in a cool atmosphere and consequentl $;$ is hardy. Stock grown in a warm. moist atmosphere is pretty to look at in the greenhouse, but when sold and taken to the window garden and exposed to sudden and severe changes of temperature, they cannot and will not flourish. It is the same with Southern grown plants: becoming accustomed to a warm and genial climate, they cannot withstand the rigors of a Northern home; with stock grown at the North and transported to the South, the reverse must be the cuse.

We have endeavored in as rew words as possible to explain the superior quality of plants grown in cool greenhouses and in a Northern climate, and now all we asi is a trial order from these pages that you may become convinced.

(From the American Garden.),

If half of them die then they will cost double price and still be very weak things. I wonder if on good strong plant is nut worth a whole lot of three cent toothpicks. If you want good plants you will get them only by paving a fair $p$ ic: for them. 


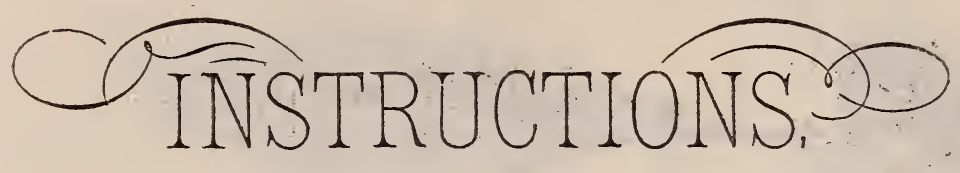

All Plants securely packed in damp moss and will go safely to any part of the United States.

Terms, cash with the order by registered letter or P. O. money order at my risk.

GuARANTEE:-I guarantee the safe arrival of all plants, and should any be damaged or lost I will replace them free of charge. A note from Postmaster or Express Agent must be sent with claim stating that none have been received at the office.

Collections. - When you have no knowledge of the different varieties of plants and wish a fine lot for general purposes, please order by collections and you wilı be better pleased. I have made ny collections of the best and finest varieties grown and with the largest range of colors.

ExTRA PLANTs. - When you receive vour goods and find more than you have ordered remember that we send with all orders extras as an appreciation of your patronage.

Mail Club Rates. - For a remittance of $\$$ I.oo you can select from catalogu $\$ 1.25$; tor $\$ 2.00$ you can select $\$ 2.50$; for $\$ 3.00$ you can select $\$ 3.75$; for $\$ 4.00$ you can selent $\$ 5.00$; for larger amonnts the same proportion. A premium is given to every $\$ 1.00$ worth of goods.

Express Club Rates.--For a remittance of $\$ 3.00$ to be shipped by express, you may select plants from catalogue prices to amount of $\$ 4.00$; for $\$ 4.00$ you may select $\$ 5.25$ and for $\$ 5.00$ you may select $\$ 7.00$. A premium is given for every $\$ 1.00$ sent by diaft, P. O. order, Express order or cash.

Treatment of Plants upon Arrival. - If the plants are in the least wilted upon arrival, place them, with the paper and all packing, in a vessel with - water warm enough to be comfortable to the hand and allow them to remain for at least one-hal hour.

SoIL.-The soil should be fibeous and composed of rotted sods $\frac{2}{3}$, and well rotted barn manure $\frac{1}{3}$, with a little sand. If sods are not to be had use any good rich garden soil with sand and manure.

Portivg.-Use pots that are not too large or too small, the mass of roots being a good guide to be governed by when potting. Press the soil gently on the sides of the pots; set in a shady place and water well; do nut water too often or the suil will become soggy and so:m. Plunging the pots in sand or saw dust is very beneficial and keeps the soil moist.

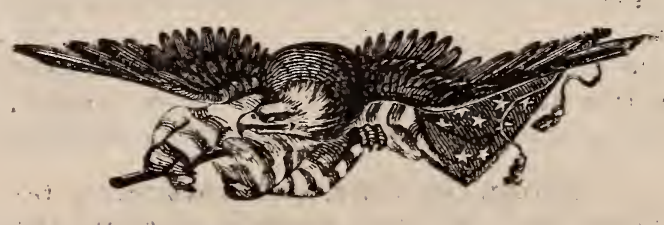




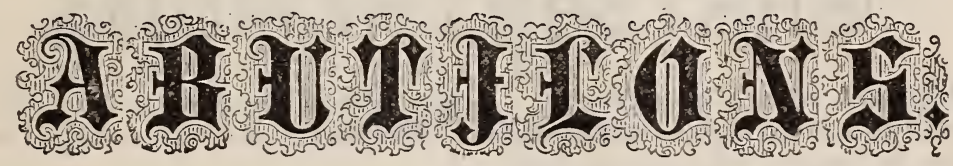

Abutilons should be given a moderately light soil mixed with leaf mold from the woods and uld manure. Abutilons have large roots and should be shifted into !arger pots as required. They are of easy culture and very satisfactory, giving a profusion of bloom the year round. They are sometimes called Flowering Maples.

Pluton.-A tall growing, stalky variety, with large leaves and flowers of an orange red color, bell shaped and pendant. Price io cts. each.

A. Besson.-Foliage light green, leares cut like a white maple, flowers oranga and borne in clusters. Price ro cts.

Gen. Logan.-Similar to A. Besson, but has darker foliage and requires more room to grow it in. Price 15 cts.

Boule De Neige.-Pure white in color, a compact grower and very profuse bloomer. The best white variety in cultivation and profuses its bell shaped flowers through the entire year. Price ro cts.

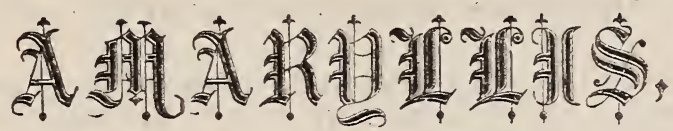

Few flowers give a better return in the shape of lasting and showy bloom for the limited amount of labor involved in their cultivation. A compost consisting of equal parts of good turfy loam; leaf-mould, well decaved manure and sharp sand, answers best for planting. From the time they are started, water should be given very carefully, and not in too great quantities. When the foliage begins to decay,water should be gradually withheld, until it has died quite down, when the bulbs may be stored away (in the pots) in any dry, cool place, safe from frost, until their flowering season comes again. Price 25 cts each,

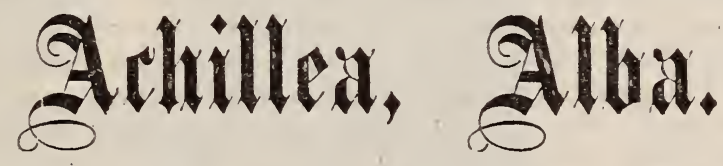

No flower is more worthy of a place in every garden in the land than this. It is a hardy perennial, the top dying down to the ground every winter. Its many branches grow to the length of two or three feet, resting on the ground, and holding their great masses of flowers about a foot abov' the soil. A plant will produce hundreds and even thousands of flowers the first summer; but when established the second year.we have had them with more than 5,000 perfect flowers on a plant at the same time. We give 5 reasons why this piant should be cultivated by EVERYBODY.

Ist. It is pecfectly hardy everywhere, and will thrive in any soil or situation, no matter how poor, and will :ake care of itself.

2d. It commences to bloom early in July, and is a perfect mass of beautiful flowers till frost.

$3 \mathrm{~d}$. Its flowers are pure white, perfectly double, and produced in large sprays, making it one of the finest cut flowers for bouquets, vases, baskets, etc., or for any kind of decoration.

4th. For Cemetery planting it is the most valuable of all flowers, as it is sure to thrive and bear its great profusiou of snow-white flowers nearly the whole summer for years and years.

5th. Owing to its great vigor and haidiness it can be planted in large quantity in any waste or out-of-the-way place, where it will produce a great abundance of beautiful flowers for cutting,

PRICES, by mail, postpaid, I plant to ary address for 20 cents; 2 for 30 cents ;'t for 50 cents; Io for $\$ 1.00 ; 25$ for $\$ 2.00$. They will all grow rapidly and produce abundance of bloom this summer." They can either be potted or plinted as soon as received.

\section{BREGMANSIA.}

(DATURA ARBORIA OR GIANT GHOST FLOWER.)

This interesting and wonderful plant, although not new, is very uncommonly met with. It has always been scarce and very rare. It is a woody shrub, growing : hout the size of an oleander, and having leaves from six to seven inches in length : d about two and one-half inches in width, somewhat resembling mullein leaves, though less downy. The most wonderful teature of the plant is its flowers, which are 


\section{굴 HRYSANTHEMUMS.}

The first light snow was falling fast;

My heart was filled with pain and grief:

I mourned o'er faith and friendship dead,

O'er faded flower and withered leaf.

Restless. I paced the garden wide,

Then felt of joy a sudden thrill-

For at my side, like veiled bride,

One snow-white flower was blooming still.

I raised the $x$ torm-bowed bended head;

Elastic sprung the slender form.
No rose of June on sunny bed

Outshone this blossom of the storm.

Teach me. I cried, thy cheerful fitith. Brave.patient flower who dares to bloom

On Winter's icy verge, and saith, Give doubt no place, aisd feai no room.

I still will trust - "You may, you m:ast"I heard, with joy and wonder dumb.

My parted love was faithful proved;

Thine augury true-Chrysanthemum. $-\mathrm{H} . \mathrm{H}$.

Those who have never seen these grand new sorts in bloom can form no idea of their great beauty. For blooming in October and November no plant can compare with them. For both out-door and in-door cultivation they are ahead of all other Howers.

How to Grow Chrysanthemins.--Plants can be planted as early as the first of April, but any time to the middle of May will be soon enough. Set them about $2 \frac{1}{3}$ to 3 feet apart each way. This can easily be done where a border cin be devoted to them alone. When grown in a mixed border, where there are other plants, a space of $z$ feet should be allowed for each Chrysanthemum; the soil must be made rich with manure. and hept clean. About the first week in June each plant should have the center of the shoot pinched out. A strong stick should at the time be placed by the side of each plant, to which it should be loosely tied. In a few weeks there will be grown from + to 6 more shoots, 4 to 5 inches long. These must again be stopped, and this operation continued until the first of August, after which time let every shoot grow and do not stop any more. Keep the plant tied so as to prevent being broken by the wi id. By the first week in September many buds will be formed, and if very large flowers are desired, une-third or more of the buds should be taken off. Snme weak liquid manure can be given, and about the frrst of October, if plants are required for in-door decoration, they can be easily dug up, potted into different size pots, according to the plants, and set in the shade for a few days. They mnst be well watered, after which they should be placed in the sun until there is danger of frost, when they should be moved into a cool room or green-house, but not be subiected to fire-heat more than t: keep out frost.

We have made Chrysanthemums a specialty, and the following list contains the very finest varieties only. After blooming they should be placed in a cellar or pit until spring.

Rubra Striata.-Ground color, creamy, lined with rose-salmon on outside of petals; flowers six inches across, magnificent. Price so cts.

President Arthur. - Flowers 7 inches across, formed of long needle like quills which open in whorls. Color rose with white center. Price $10 \mathrm{cts}$.

Incomparable.-A splendid mottled or variegated variety; rich chrome yellow and coppery red. Price ro cts.

Blanche Niege.-Immense sized flowers, petals tubular and of the purest snow white. An extrat variety. Price $10 \mathrm{cts}$.

Sunrise.-Yellow, outside petals slightly tinged with crimson. Price so cts.

Contrast.-Rich dark crimson petals, with orange-yellow centre,petals quilled and in whorls. ${ }_{15} \mathrm{cts}$.

\section{COBEA Scandens.}

Handsome, free-tlowering, climbing plants, growing rapidly, with large bell shaped flowers. They are among our best Summer climbers, and are excellent for training in the green-house and conservatory, especially the variegated-leaved variety, the leaves of which are beautifully marked with creamy white. 20c. each.

\section{Calla.}

Calla Ethiopica (Lily of the Nite).-An old, favorite plant which should be 
found in every collection. It grows freely and requires an abundance of water, and produces large, pure white blossoms during the winter and spring. The resting period during June and July can be given by turning the pots on their sides, without watering, in a shady place. Price from io to $30 \mathrm{cts}$.

\section{Calceolaria.}

Another exceedingly showy house piant. which when in bloom, is, indeed a rare beauty, havinu hundreds of showy pocket-like flowers of various colors. Give plenty of water and partial shade. Gold spotted with crimson. Price Ioc. each.

\section{Dew Plant.}

A good plant for hanging baskets. Leaves light green and sparkling as though covered with dew. Bright pink blossoms. Price $5 \mathrm{c}$. White foliaged. Price roc.

\section{Fuchsias.}

These, with their glossy foliage and delicate bell-shapen flowers, form one of the most attractive of plants. Bedded in the garden, they should be placed so as to be shaded most of th: div; they $\mathrm{d}: \mathrm{i}$ sht in moisture and a rich soil.

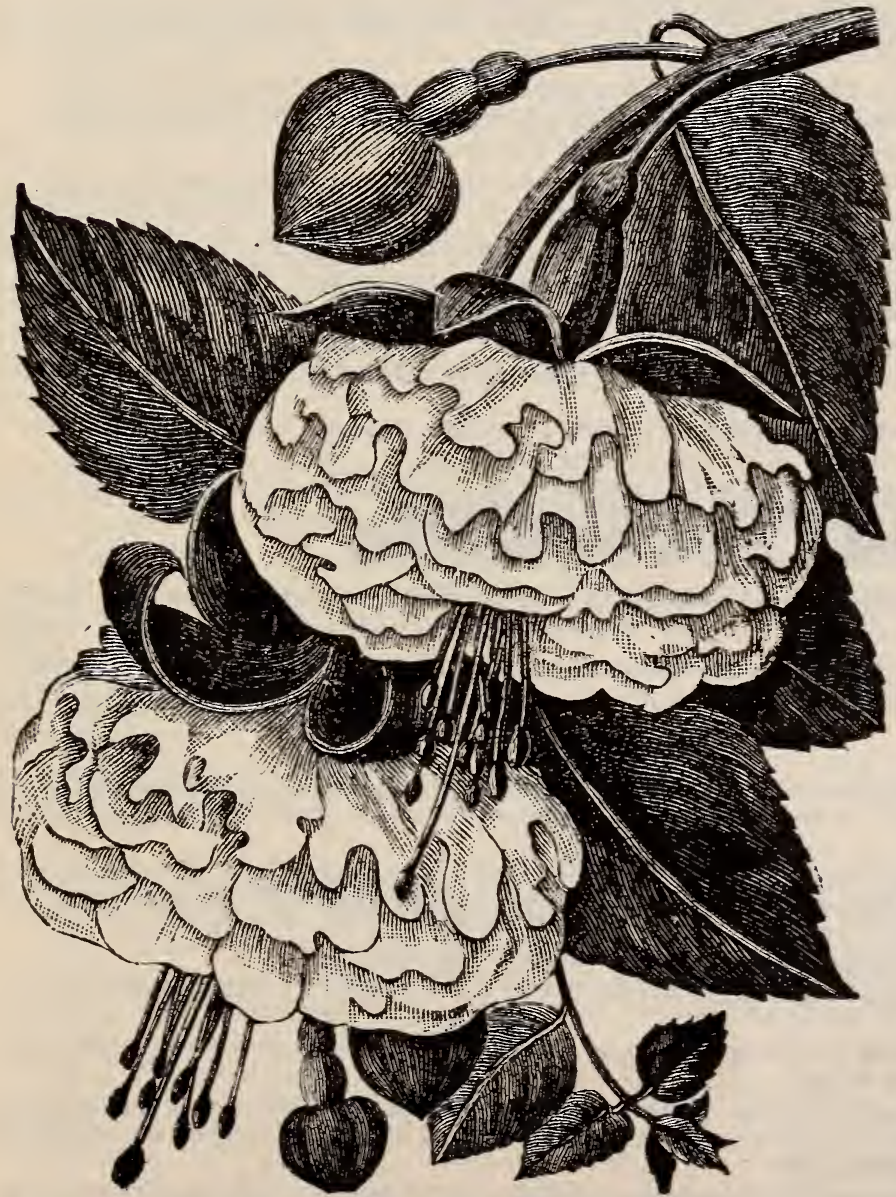

PHENOMENAL.

The largest $F$ uchsia yet produc. ed. Flowers twice the size of any other Fuchsia in cultivation. We had an oil painting made, natural size, of a flower grown in $0^{*}$ greenhouse the past seasor is bloom actually measured three and onehalf inches across. This variety is a tall, strong growing sort and a most wonderful plant. Corolla purple, sepals carmine red. Price. only 15 cts.

\section{STORM KING.}

\section{(Frau Emma Topfer)}

This sort is known and cultivated everywhere and is as good as ever. It may be described as follows: This beautiful novelty is a decided acquisition, and deserves 2 place in every garden. Our stock is genuine, and we give the description of the introducer "This grand plant is of the most beautiful weeping habit. The branches, drooping as they do, lend the plant a charming grace which is rarely found. Branches numerous, leaves small and nu. merous, and of the most beautiful glowing healthy green; the buds, for two weeks before they expa are balls of glowing scarlet cri. son. The sepals are of the sam. glowing scarlet crimson as the buds, while the large double corolla is of delicate waxy whiteness, elegantly penciled with deep bright crimson. Its flowering qualities are most remarkable, for it is never out of bloom when in a healthy condition. Tokeep a plant bloom ing all the time, many of the buds mist at times be removed, or the plant will bloom itself to death."

We shall have about $\mathrm{r}, 000$ strong

plants warranted genuine, which we shall offer at the low price of $10 \mathrm{cts}$. each.

Mrs. E. G. Hill.-This magnificent variety was raised and introduced by Mon. Victor Lemoine, of France, and is undeniably the most perfect and beautiful double white Fuchsia ever raised. The short tube and sepals are a bright. rich reddish crimson color; corolla, extra large, full and double; flower of the l.rrgest size. In all, save color, it is like Phenomenal, and it would not surprise us if some enterprising Yankee should name it White Phenominal. It is of the most robust, upright growth, not coarse, 
of enormous size, being over one foot in length and seven or eight inches in breadth, bell shaped and of a pure white color, drooping like fuchsias, sweet scented and borne in profusion. A lady living in Massachusetts had a plant of this kind which bore seventeen perfect flowers at one time. A florist while riding by the house one day noticed this plant in the window. He called and bought it of the lady. paying her fifteen doliars for it. It requires plenty of moisture and sunshine and blossoms every month from April until October. Price only $20 \mathrm{cts}$. each.

\section{BEGONIAS.}

Begonias require a sandy soil intermixed with old well rotted cow manure and leaf mold, and given a more or less shady position.

REX VARIETIES.

The most ornamental of window plants when w ell grown. Give them a soil composed of rich loam, woods earth and sharp sand. They require a warm, moist atmosphere, and a shady situation; suitable for wardian cases. They are universally admired for their grand leaves, which are elegant in form, rich in coloring, and of the deepest velvety texture. Do not allow the sun to strike the leaves while wet, and do not over-water. I5 cts.

FLOWERING VARIETIES.

Hybrida Multiflora.-Leaves exactly the size and shape of the briar roses. I'abit upright, branches rising singly from the root. Flowers rosy pink. Io cts.

Metallica.-Dark, rough leaves; the surface a lustrcus bronze green; veins depressed and dark red. A free bloomer. The unopened buds are bright red, with surface like plush. When open the flower is waxy white. ro cts.

Weltoniensis.-This is the most widely known of the species; heavy velvety shadings of black ap. pear on the maple-like leaves, every branch bearing its delicate bunch of rosy pink bloom. $10 \mathrm{cts}$.

Bronze Weltoniensis.-Similar to the above only bronze flowered. I5 cts.

Rubra.-If you only have one Begonia, let it be a Rubra, for it will be a constant delight. It is so fast-growing that it will in a year or two reach the top of your window, sending up heavv, stiff canes, an inch in diameter, and rising beside them will grow strong, slender branches, gracefully drooping under heavy waxen leaves and pendant panicles of coral-colored flowers as large as a hard. We have seen a medium-sized plant with more thar twenty such panicles at a time. Among the individual flowers you will find three distinct forms growing side hy side. One of the most wonderful plants within our knowledge. Price io cts.

Silver Fleece.-Smooth silvery leaf, with high luster and narrow dark edge; a free growing variety. Blossom pure white. Io cts.

Goury.-A smooth, small-leaved, erect. variety; flowers pale pink. ro cts.

\section{Carnations.}

They thrive in a cool atmosphere-about $50^{c}$ at night; warm sunshine during the day is beneficial. Sprinkle the foliage frequently but do not give too much moisture at the root; allow the soil to become dry, then water thoroughly. Enrich a good garden soil with well-rotted cow manure or bone dust, and keep the plants tied up to stakes.

Ida May.-A new variety which we recommend to all as one of the finest in cultivation; color, rich creamy, marbled and splashed with carmine; prolific in bloom, and the strongest on our list. Price 25 cts.

Pride of renshurst. - We consider this variety the choicest novelty in Carnations sent out in years. The flowers are large, full and double, and are pure, rich golden-yellow, without stripes of any kind. A strong grower and free bloomer, and decidedly the best yellow yet introduced. Price 50 cts.

Anna $W c b b$. - One of the very best dark reds ever introduced. Price is cts.

Buttercup.-Of a deep rich yellow, like Marechal Neil, with a few streaks of clear carmine, a very near approach to a pure yellow. Price $i_{5} \mathrm{cts}$.

Chester Pride.-One of the most desirable Carnations for winter flowering; pure white, striped and penciled with rosy-carmine. Price $10 \mathrm{cts}$.

The Century.-It is of remarkably strong, healthy growth; medium height; early and constant blooming; of a rich, glowing carmine color; does not burst the calyx; is full and double and has a renarkably rich clove fragrance. Price 15 cts.

Ilinzey's White.-One of the finest white Carnations in cultivation; flowers very large and of perfect shape; color white with a delicate tint of pink; rich clove fragrance. A continuous bloomer. Has no superior as yet, taking all its good qualities tógether, but not an absolute white on first opening. Color beautiful. io cts.

Grace Wilder.- One of the most beautiful colors among Carnations, a soft shade of carmine pink. A dwarf, but robust grower. Very desirable. Cultivated by thousands around Boston: io cts.

Silver Spray.-Raised by Simmons, and a variety of great worth. S1rong, robust, but very dwar in habit, rarely exceeding fifteen inches in height, but of bushy, compact growth. Unusually free bloom ing; flowers produced on long stems, very large and perfectly tormed. Never bursting, pure white in color, and beautifully tringed. Price ro cts. 
hut comnact and verv symmetrical. It has everv q ualification to recommend it, both size, freedom of bloom and good constitution. Must and will win its way into favor everywhere. I5 cts.

Cleopatra.-Very large and double corolla of an azure blue color, passing to dark violet. Extra tine. Iorts

Elm City.-Sepals rich crimson in color, enclosing the violet purple corolla, forming globular balls. One of the very best. Io cts.

Lustre.-A very beautiful single variety; corolla rose pink, tube and sepals white. Io cts.

Venus Vitrex.-Single, corolla dark purple, tube and sepals white. Io cts.

\section{Farfugium.}

A first-class ornamental plant for pots, well adapted for house culture. The leaves are thick and leathery, dark green, with yellow spots; an excellent plant for center of hanging basket. io cents.

\section{Featherfew.}

A beautiful plant having deep cut dark green foliage, and bearing a profusion of double, pare white blossoms. Io cts.

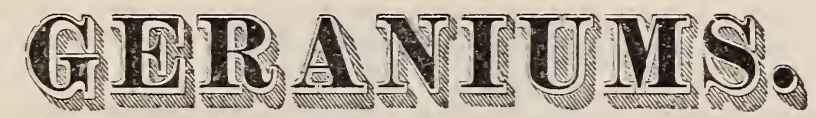

DOUBLE VARIETIES.

These beautiful plants are too well known and admired to need comment. We have a large stock of vigorous plants. None but first class varieties are here offered

Bruant.-Color, light rermilion; trusses large and carried well above the foliage. Io cts.

Baron Duranteau.-A magnificent dark crimson variety, with purplish tinge. Io cts. I5 cts.

Evangeline.-Color white, slightly tinged with pink in warm weather. A first class white rariety.

Guillion Mangelli.-Rich crimson; trusses as large as coffee cups, the largest of any variety in cul tivation. Io cts.

Gilded Gold.-Rich dark orange, the nearest approach to yellow. ${ }_{15}$ cts.

M. A. Hunt.-Orange salmon, with capucine and bronzy shades. Very showy. ro cts.

Mary Hill.-One of the newer sorts; color, bright rosy pink, with large white center; flowers immense size; trusses medium. I5 cts.

Queen of lhe Fairies.-A bi-color variety of the most perfect shape, rich flesh color, mottled with pearly white. Io cts.

Maiden's Blush.- White, finely flaked with rose, beautifully tresh and delicate. Io cts.

Satisfaction. - A grand variety of splendid habit of growth; flowers very large; color carmine shaded crimson; it differs from any other variety in its soft and finely toned coloring. Io cts.

Negress.-The most double and the darkest geranium we know. $10 \mathrm{cts}$.

Emily Lemoine.-A very double pink and beautiful sort. Io cts.

Golden Daznn.- The color as the name would indicate is of a decided golden orange shade: t: e Howers are of fine large size and perfect shape. The habit of the plant is all that could be desired. Io cts.

Bac-ninh.-Immense spherical trusses of large, perfect formed florets; centre beautiful salmon, petals bordered with lively red. A very distinct and fine variety. Plant of short-jointed and very free blooming habit. ${ }_{5} \mathrm{cts}$.

White Swan.- A new variety of a dwarf bushy habit, bearing in great profusion large trusses $r f$ large double snow white flowers, which are exceedingly perfect and beautiful. It is without do.sbt the finest double white sort in existence. $15 \mathrm{cts}$.

\section{SINGLE VARIETIES.}

Mary Hallock Foote.-Immense trusses of light salmon; individual flowers very large and of the mosi perfect shape. The most beautiful single geranium within our knowledge. 10 cts.

Gen. Grant.-A superb bedding variety; trusses large; color, bright scarlet. Io cts.

King of Scarlets.-Flowers dazzling scarlet. A fine single variety. Io cts.

Anna Scott.-Very rich, deep crimson, finely shaped flowers shaded with maroon; trusses of good size and very freely produced. Io cts.

Favorite.--Delicate pink. A charming shade. Io cts.

Princess Maude.-A rare variety, with large flowers of perfect outline, rich scarlet, with large, white eye. Io cts.

Mr. O. M. Ruchardson, Dear Sir:-I received my plants to-day and am more than pleased with them. They were just as fresh as though just taken up, with scarceIv a leaf jammed. I don't see how you can afford to give so much for the money. Many than'ss for the extras. When I want more plants I shali send to you.

$$
\text { Yours truly, Mrs. Johx Olsox. }
$$




\section{Geraniums (continued).}

Perle-Trusses large and of very perfect form; pure snowy white, purer in color than the variety "Queen of the Belgians," and of still freer blooming habit. 15 cts.

Sunshine.-A seedling raised by ourselves. A very vigorous grower with large trusses of beautiful perfect flowers. Color, rich salmon pink shaded to white at the edge, and white eye. $10 \mathrm{cts}$.

Mrs. Crawford.-A seedling. When well grown the foliage is immense, of a bright green, with : zone so broad and dark as to give it almost a black appearance. Blossoms of a rich scarlet with white eye. Medium size truss and flower. A distinct variety and very heautiul. $15 \mathrm{cts}$.

\section{VARIEGATED GERANIUMS.}

Prince Bismark.-Foliage yellowish green, with narrow zone of deep chocolate; flowers salmon, tipped white; a splendid variety. $15 \mathrm{cts}$.

Happy Thought.-Instead of the usual outer belt or margin, in this instance the color forms a large conspicunus cream yellow blotch in the centre or disc of the leaf. The flower is a rich magenta rose, tinted with scarlet. 8 cts.

Mudame Salleroi.-Leaves from nne to two inches in diameter, the center of each is of deep olive greet, with broad margins of pure white; growing in dense round masses. It is not effected in th sli rinest degree by exposure to the direct sunlight. ro cts.

Mountain of Snow.-Green leaves with pure white margin, flowers scarlet. 8 cts.

Corinne.-Double, clear scarlet flower; leaf yellowish green with light c'locolate zone. ${ }_{5}$ cts.

SWEET SCENTED.

Fern Leaved.-Leaves finely cut, giving the plant a fern-lik z uppearance. Io cts.

Quercifolium, or Oak Leaf.-Center of leaf black with light green margin. 1o cts.

Pennyroyal, Flush Leaved.-Leaves large, light green with darker veins, and covered with hairs like plush. Very beautiful. ro cts.

Rose.-The most fragrant of all; deeply lobed leaves. 1o cts.

Lemon.-Foliage lighter green, but much resembling Rose. Io cts.

Variegated.-Green and white, spicy fragrance, very beautiful. Io cts.

\section{Heliotrope.}

These plants are universal favorites on account of their delightful fragrance. They delight in abundance of water. Io cts. each.

White Lady. - The flower is extra large, of the purest white.

Albert Delaux.-A French variety of great beauty. Foliage is a bright golden vellow, very pronounced, and marked slightly with a delicate green. In bloom it is exquisitely beautitul, the deep laven. der color of the flower contrasting admirably with the ever varying foliage; very free flowering; trusses large.

Sapphire.-A beautiful light lavender in color; producing immense quantities of very fine trusses of bloom. This is the very finest $\mathrm{F}$. eliotrope in its particular line of color, and we recommend it for bedding.

\section{Wax Plant (Hoya Carnosa).}

Has thick, fleshy leaves, growing moderately fast, and bearing umbels of beautiful flesh colored flowers, from which are exuded large drops of honey-like liquid. One of the best plants for house culture, as it stands the extremes of heat and cold better than most plants, and is not easily injured by neglect. It can be trained to climb on trellis work to almost any height, and when in bloom, which continues for upwards of five months, is a most interesting plant. Io cts.

\section{Hydrangea.}

The Hydrangea is probably the finest hardy flowering shrub in cultivation, with very large, dense flower-heads, 6 to 12 inches in length. These panicles of bloom remain from August to October.

Thes. Hogg.-Immense trusses of flowers, at first tinged with green, then turning pure white and remaining so a long time. $15 \mathrm{cts}$. each.

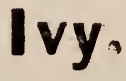

German,-A vine of rapid growth, beautiful dark green glossy foliage, excellent for covering walls. arbors, etc. ro cts.

English.-The well known European variety. ro cts.

Varlegata.-Foliage marked white. I $_{5}$ cts. 


\section{Ivy Geraniums.}

Count Horace du Ch vivelul.-Flowers of grand size, petals imbricated; pale blush, bordered with salmon. Very free flowering. First class. 15 cts.

feanne d'Arc.-Flowers very large and double, and of the purest white; fine spreading habit and free flowering; distinct and fine. $x_{5}$ cts.

\section{Lantanas.}

One of the best Summer-flowering trire of plants for our climate; equally fine in dry or wet weather, sun or shade. There are tew bedding plants that bloom more continuously or afford a greater variety of color than the Lantana. When grown with a single stem and trained as standards, with fine bushy tops and straight stem. besides being in bloom all Sum is not surpassed by any other plant.

Innocence.-Pure white flowers; wonderfully free; of str ing growth; best white. Io cts.

Facques Minot.-Orange, changing to bri rht orange-yellow and red; exceedinglv fine and showy; it grand and brilliant variety. One of the very freest in bloom. 15 cts.

Francine.-Dwarf growing; flowers rosy lilac; ve.y p etty. $10 \mathrm{cts}$.

\section{Maderia Vine}

The flowers of this climber are feachery white, with the fragrance of the Mignonette, grows fifty feet high or more in one season. $5 \mathrm{cts}$.

\section{Oleander.}

As a rich plant this has no rival. All the inproved varieties bloom firom Mav till Octsber, very profusely. They can be kept over winter in any kind of cellar or pit in which it does not freeze. They love plenty of water and rich ground well $\mathrm{m}$. nured. If the plants grow ton high, plant them out in open ground and cut dow two or three feet, and hundreds of young shoots will come up. forming nice bushy plants.

Rosea Splendens.-The best of all. Flowers perfectly double, very large. $25 \mathrm{cts}$.

\section{Passion Flower.}

Constance Ellintt.-This will certainly become one of our most p pular climbers. It is a rapid climber with beautiful green foliage, and would be valuable if it did not bluom. The flowers are pure white, with delicate colosing at the base of corolla. Will stand our severe winters if protected by mulching. Unexcelled tor bay-windows. $10 \mathrm{cts}$. 


\section{Roses (Continued).}

Catharine Mermet.-A very beautiful Tea Rnse, valued highly for its elegant buds; color, clear shining pink, with delicately shaded amber and fawn centre; large, globular Howers; one of the very finest varieties; a strong healt'y yrower and good bloomer. Io cts.

Perle Des Fardins. - This magniticent Rose still retains its position as the finest Rose of its color ever introduced. It constantly grows in favor as its merits becume better known. Colnr, clear golden yellow; very rich and beautiful; extra large globular flowers, very full and highly perfumed. 10 cts.

La France.-This Rose is a general favorite, and is the sweetest of all roses; color, silvery rose, changing to pink; very large and full: olnhular; a most constant bloomer. Io cts.

Marie Van Houte.-Pale yellnw, culge.., petals often lined with rose, well formed, of good habit, and in every respect a most charmi in sort: t.je finest Tea for out of door culture. $1_{5} \mathrm{cts}$.

The above six for 50 cts.

\section{Bridal Rose (Rubus Grandiflori.}

Large, double, pure white flowers, very thowy and desirable. Scts.

\section{Salvia.}

The Salvia is of easy culture attaining a height of two to three feet. The flow ers are very attractive, especia ly the scrlet and variegated varieties. Io cts. each.

Greggi.-A most beautiful new viri.ty: ve free flowering; bloms continuously through the Sum mer. The flowers are rather small. but are of il most brilliant cherry color. One of the most desirable

Splendens.-One of the finest of Fulf bio ming plants, being completely covered un Autumn with long spikes of lazzling scarlet Howers, remaining in bluom until cut down by frost.

M. Issanchon.-Creamy-white flowers, evenly variegated with scarlet; plant dwarf and free flowering. The best variegated sort we have seen.

\section{Smilax.}

A popular and well known climber, with foliage of a dark glossy green; used largely with cut flowers, particularly wreaths; in excellent plant for parlor or wincow culture. $20 \mathrm{cts}$.

\section{Cloxinia.}

These are among the most beautiful of all our Summer blooming greenhouse plants. The rosette of velvety green leaves is surmounted with a cluster of lovely trumpet shaped flowers. The coloring is exquisite; the groundwork of many is pure white, with throats of blue, scarlet rose, or crimson; or the tubes are of bright color, with white throat. The bulbs should be started in a warm place-greenhouse, hotbed, or sunnr winjow. They will bloom until late in Summer, when they shorld be dried off, letting the leaves die; the pots can be kept over winter in a cellar free from trost, or under the stage of a greenholis. Stmon...

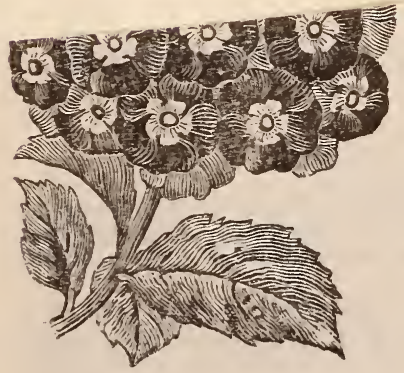

\section{Verbenas.}

The Verbena is the most satisfactory of all bedding plants and is grown in popularity yearly. They also make fine blooming plants for the window. In growing them be careful and have no leaf mold in the soil. but give them a good rich loam and plenty of sunshine. WVe offer Henderson's mammnth strain in variety at jc. each, 5oc. per dozen. 


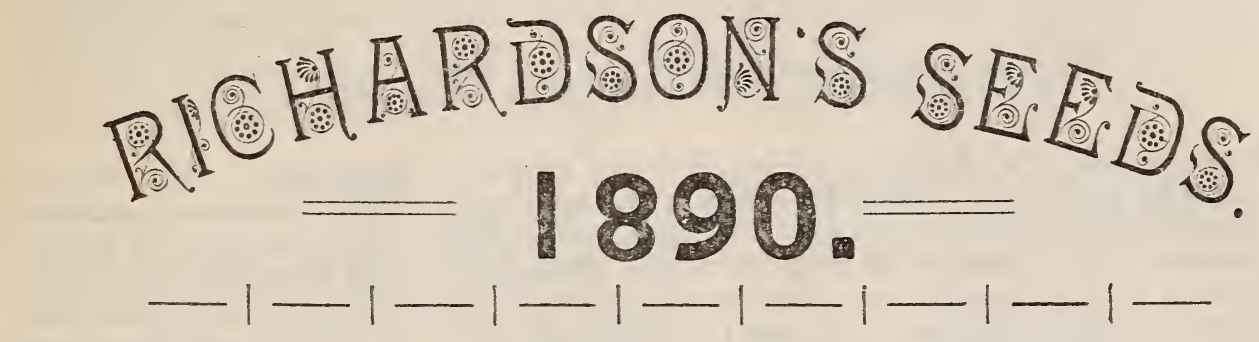

$-1-1-1-1-1-1-1-1-1-1-1-1-1-1-1-$

The planting of seeds should be largely governed by the size of the seeds. Peas require to be planted deep. Beans about an inch deep. Cabbage, Turnips, Radish and other seeds of this size should be planted about one-half inch deep. Beets, Melons, Cucumbes. Pumpkins, Squashes and the like about one inch deep. Onions, Tomatoes. Peppers. Sc. about one-half inch deep. In the planting of flower seeds the same rule applies. Verv fine seeds like Portulacca, Poppies, \&c. should be planted on the sus face of the soil and slightly pressed in with the hand. Fine seeds grow much better if shaded until they come up. Mosi flower seeds should be planted about one lourth inch deep and the soil pressed down slightly on the surface. Some of the larger seeds shisuld be planted slightiy deeper.

The varieties named on the following pages are only the very best varieties and nothing will be gained by selecting from a larger list.

The seeds usually sold at the corner grocery are always of doubtful puritr. They are sold to the merchant with the understanding that he is to return what is left. over. These old seed-are taken the next season and mixed up with the new crop nd wold to the grocervman as before.

We warmat the reeds here offered to be fresh and of strong germinating power. and as we pay the postase on everything it costs you no more to send to us than to purchase them at the store. Remember in planting seeds of doubful purity you are running a great risk for should they fail there is no time to remedy it and the seasun's work is entirely lost.

Remember everything here offered is warranted to give satisfaction in every particular, should such not occur we will cheerfully refill the order or refund the money in every case.

\section{Our Rraines}

is growing so rapidly that we have hard work to keep up with it. We have customers in all parts of the country. You may get some id zay of the way our customers are satisfied when we tell you of the fact that should our business continue to increase for the next ten years at the rate that it has increased since we started it will amount to over half a million dollars annually.

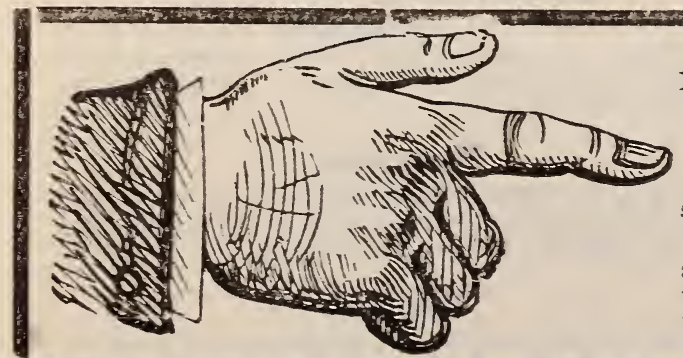

For $\$ 1,00$ you may select seeds to the amount of $\$ \mathrm{r} .20$

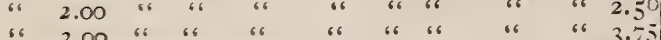

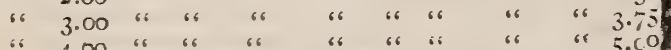
Aside from this we always give a few plants or seeds or both gratis with every order.

By getting your-neighbors to send with you and combining the orders you may thus take ad rantage of these discounts and get a good collection for vour garden free. 


\section{$=-1-1-1-1-1-1-1-1-1-1-1-1-1-1-1-$}

\section{Noodbury's Fimous Pansies.}

We have secured a quantity of this celebrated strain of Pansy seed. Mr. Woodbury's pansies have been praised by many of the best judges in this country, and the frontispiece of The American Garden for November, ISS7, was a bouquet of Woodbury's pansies. L. Templin \& Son, of Ohio, florist, say th.t Woodbury's pansies are the finest in this country and superior tr) any of the G sinan, Imperial, and o.her sold so extensively throughout the countrv at high prices. The Estern Farner says "They are the most exquisite specimens that we have ever seen." We olfer them at the low price of $20 \mathrm{cts}$. per pkt. of 100 seeds.

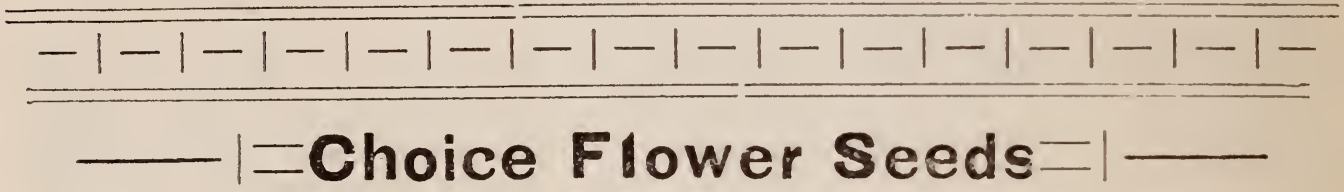

\section{Astor.}

This splendid class of plants is not nnly nne of the most popular, but also nne of the most effective of nur garden favorites, producing in profusion flowers in which richness and variety of colnr are combined with the most perfect and heautiful form. For flower-beds and mixed botders, it stands unrivalled. Asters delight in a deep, rich soil: and during the hot weather, mulching witl coarse namure is very beneficial. For early bloming. sow ial hot-bed. Mixed, per pkt. 5 cts.

\section{Alys sum.}

The sweet Alyssum has small white flowers, and is very much used in making houquets, and with re'y grood effect, also make pretty burders. IIardy annual six inches high. Per pkt. 5 cts.

\section{Balsam.}

Balsam is a very popular annual, with gond care and a rich soil plants and flowers of great beauty are produced. The Balsam can be pruned to any form desired and well repays the extra care. Mixed, per pkt. 10 cts.

\section{Annual Chrysanthemum, Golsen Feather.}

The beantiful, large, daisy-likr flowers are 2 I-2 th 3 inches across; the dark, velvety disk in the centre is surrounded by a circle of bright golden vel. lnw, followed by another clear-cut circle of rich crinson, as clearly defined from the nuter white as if painted. The most distinguishing feature $i-$, that it has beatutiful golden foliage. Per pkt. $10 \mathrm{cts}$.

\section{Cineraria.}

Maritima. (Dusty Miller).- Very ornamentil for bedding and as a decorative plant. Of dwarf,compact habit, with handsnme silvery-white fnliage. 'This can be grown very easily from secd: it is one of the most attractive of border plants, and is universally admired. Per pkt. 5 cts.

\section{ปanjytuft.}

Candytuft is one of the most popular and usetul little flowers. It is so hardy that inost kinds may be sown in the ealliest spring or even in autumn. The flowers grom in the form of clusters. Per pkt. 5 cts.

\section{Dianthus.}

The varieties of Dianthus known as Japan Pinks and Chincse Pinks are among the most brilliant of our garden thowers. The tall species grows fitteen inclies in height, while the dwarf species makes a low compact plant. The seed should he sown in the spring. Mixed colors per pht. $10 \mathrm{cts}$.

\section{Everlastizgs.}

These are very popular and desirable for winter decoration, bo uefuets, wreaths, etc. They should be cut when ther come into full blonm, tied into bunclies and dried in the shade. Per pht. 5 cts.

\section{Godetia.}

Plants easily cultivated, and will produce a great quantity of flowers, of very hrilliant colors. In Hower Julv to September, Mardy anmuals. 1 foot. Per pht. 5 cts.

\section{Lebelia.}

Handsome little plants, admirably adapted for borders, vases, pots or hanging baskets. II alf hardy annuals. Per pkt. $5 \mathrm{cts}$.

\section{Larkspur (Delphinium).}

Very elegant and ornamental plants, producing in great variety of form and color some of the most beautiful flowers in cultivation. They flourish in any soil or climate, and blonm with constant profusin throughout the summer and fall. Hardy annuals. Per pkt. $5 \mathrm{cts}$.

Marvel of Pel a (Mirabilis:.

This is the fine old garden plant known as Four o'Clncks. It succeeds well in any garden soil; : very showy and popular flower. Hardy annul. Mixed, per pkt. 5 cts.

\section{Mignonette.}

A well-known and universal garden favorite, and one that requires no extra instructions for growing. Hardy annual. Mixed, per plit. $5 \mathrm{cts}$.

\section{Marigo'd.}

The African varieties are larger flowers than the French. African double mixed, per pkt. 5 cts. 


\section{Nastu "tium.}

For showy and constant bloow few garden flowers equal the old Nasturtium, which, by the way, has been greatly improved during the past few years, in colors and habit of growth. They are sure to bloom in any situation, hot or cold, wet or dry. and no garden can be complete without a tair representative of them. Mixed, per pkt. 5 cts.

\section{Petruia.}

For years the Petunia has been one of the leading window and garden flowers, and few can be more generally satisfactory. Always full of bloom, it is ever an object of great beauty. The double and large single sorts are usually selected for window cuiture, and blom freely at all times of the year. For bedding out in summer they are equally valuable. A bed of Petunias is a mass of gay colors from carly spring to late fall. Per pkt. 5 cts.

\section{Double Poppy.}

This grand nld flower is tast gaining the universal popularity which it justly merits. Having for years been crowded out of our gardens by the swarm of new comers, and forgotten, it has never theless kept pace with the march of improvement and now comes around and surprises us with its new forms. new sizes, new colors, and the dear old flower, which our grandmothers loved so much, again occupies nne of the first places in our gardens, and we are nroud of it and well we may be, for through June and July it stands without an equal, the showiest of all annuals. Seed should be sown in the npen ground as early as possible. Price per pkt. 5 cts.

\section{Pa isy.}

This attractive plant is ton well known to require any description, as it is a favorite with all; if grown in beds, ribbons, or massing, they are very effective. The best plants are obtained from seed sown in the autumn, and protected during the winter; these Hower early in the spring. The plants from spring sowing should be planted in a shady border; they produce fine large flowers in the autumn. Pansies require fresh soil, enriched with decomposed manure; hardy perennials; six inches. Good mixed, per pkt., 5 cts.

\section{Portulasa.}

One of the finest hardy annual pla. $t s$, of easy culture, thriving best in a rather rich, light loam, or sandy soil, and luxurlating in an expcsed sunny situation. Per pkt. 5 cts.

\section{Phlox Drummondii.}

For brilliancy of color, the Phlox Drummondii is excelled by no other annual or perennial, the color: range from pure white to deep crimson. Seeds may he sown in the open ground or in a hot-bed; the plants should be set about one foot apart. All vari. eties mixed, per pkt. $10 \mathrm{cts}$.

\section{Sweet William.}

The best varieties of Sweet William are of very beautiful colors, very large, and almost perfect in form. The plants are perfectly hardy, and inay be increased by division of roots. Double,per pkt. $5 \mathrm{c}$.

\section{Sweet Peas.}

Most lovely and beautiful, fragrant and free-flow ering climbing plants. Cut blonms placed in vases of water last many days, emitting a most delicious perfume, approached by no uther flower. The distinct colors are very beautiful. They form admira. ble screens for protecting more tender plants and hiding unsightly objects. Plant them early, make a trench six inches deep, spread manure in bottom and cover with dirt, making the trench five inches deep in which to plant the seed, support with brush or a trellis when one font high. The oftener the flowers are cut the more you will have. Don't fail to plant some this year. No flower garden is $10 \mathrm{~m}$. plete without them. Mixed, per pkt. $5 \mathrm{cts}$.

\section{Ten Weeks Stocks.}

The Stnck is, without doubt, the most popular German flower. With its great variety of fine col. ors and large spikes of beautiful double flowers, suitable either for garden or pot culture, it is certainly one of the most desirable of all flowers. We recommend starting seed under glass and transplanting to the garden ahout the first of June. For pot culture a four or five inch pot is suitable for one plant. Per.pkt. 5 cts.

\section{Verbana.}

Th1s is a well known and universal favorite fur both pot and open ground culture. A good bed of Verbenas is usually the most attractive spot in the garden. Per pkt. 5 cts.

\section{Zinnia.}

Double Zinnias are quite an acquisition to our list of garden farnrites; of branching habit and splendid brilliant colored double flowers, rivaling the Dahlia in beauty and form. The seed can be sown early in the hot-bed and transplanted, or sown later in the open ground; half-hardy annuals; two feet. Per pkt. 5 cts.

\section{$-\div-\| * * * * * * *+1$
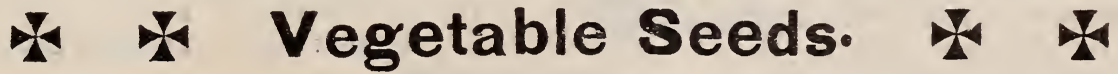

\section{Beets.}

Edmand's Blood Turnip.-Of handsome, round shape, the skin is very deep blood-red in colur, the Hesh also very dark, and exceedingly sweet and ten der in quality. The beets grow regularly, of good marketable size, not growing over-large and coarse, as do many sorts of the turnp beet wnen they have plenty of ruom. This characteristic, together with the fact that the top grows very small, and having but a single tap root, allows their being grown very close together. They mature early, and have given the very hest satisfaction as a bunch beet in the inarkets of Boston. 'They gr, $w$ slowly but of ex cellent quality, tops small, making it very desirable for bunching. Per pkt., 5 cts.

Eclifse.-Our strain is very true: much seed of. fered is badly mixed. This is without doubt the best variety of the early sorts, and as its excellence hecomes known it is rapidly coming into favor. It is very early, maturing next to the Egyptian. The bulbs are of a bright scarlet color, very smooth. Globular in shape; quality is excellent and mnch better than the Egyptian. Highly esteemed by mar. ket gardeners. Per pkt., 5 cts.

Lane's Imfrowed Sugar.-One of the very best and most nutritious varieties for feeding cattle. Per pkt., 5 cts. 


\section{Cabbage.}

Fottler's Improzed Brunsivick. - The earliest of the large heading drum-heads, in great favor with market-gardeners in all sections; used generally as a second early crop; also one of the best for a late crop, producing very solid heads, weighing from 20 to 30 pounds each. Per plit., $5 \mathrm{cts}$.

All Seasons.-A new variety that is becoming quite popular. The heads are of large size, round, flattened at the top, and are ready to market nearly as early as Early Summer, while they are hard and solid, and keep well for winter cabbage. Per pkt., IO cts.; oz. 40 cts.

Burpee's Surehead.-Produccs large, round, flattened heads, of the Flat Dutch Trpe, and is remark. able for its certainty to hesd. It is all head, and al "ays sure to head, even where other varieties fail. The heads are remarkably uniform, very hard, firm and fine in texture, and ordinasily weigh from io to 15 pounds each. It is very sweet flawned, has scarcely any lonse leaves, keeps well and is good for shipping. Per pkt., 5 cts.

Early fersey Wakefield.-The standard early variety in New York market, of large size, fine qual. ity, and sure tu head. Per plit., 5 cts.

\section{Carrots.}

Burpee's Improzed Long Orange-This is a de. cided improvement over the ordinary Long Orange. The ronts grow remarkab!y uniform and smooth, heing always well formed, and of larger size and deeper orange color. The length of the ront is about six times its diameter, and though it pene. trates the scil deeply, it also grow s about one-quarter of its entire length. Highly nutritious. Per pkt., $5 \mathrm{cts}$.

\section{Celery,}

Dwarf Golden Heart-A rery popular and distinct variety. In habit of growth it resembles the Hall Dwarf White sorts, except that when blanched the heart, which is large and full, is of a waxy golden yellow It is a most striking and showy variety. It is entirely solid, of most excellent flavor, and keeps well. Per. pkt. 5 cts.

\section{Cucumber.}

Eurly' Green Prolific, or Boston Pickling.-Under the former name best known, this cucumber is, by Massachusetts gardeners, called Boston Pickling. It is sufficient praise to say that it is equal to the Arlington or Peerless White Spine. for pickling, and that it is immensely productive. Per plit. 5 ctr.

Early Green Cluster.-A short, prickly, seedy variety, bearing in clusters near the root: color pale green. It is a great bearer and matures early. Per pkt. 5 its.

IMPROYED EARLY WIITE SPINE, or ARLINGTON. - For both market use and pickling this variety is now more is of the true original Boston market excellent for forcing. Per pkt. 5 cts. stock, and is vastly superior to the old White Spine, which we have discontinued to grow. Narket gardeners and pickling establi-hments have here a cucumber that is admirably surted to their wants. Per pkt. 5 cts.

\section{Onion.}

YELLOW GLOBE DANVERS: popular Boston market Onion; of mild flavor: very productive, and a good keeper. Per pkt. 5 cts.

\section{LARGE RED WETHERSFIELD.}

Larger, and about ten days earlier, than the preceding variety; an excellent keeper. Per pkt. 5 cts.

\section{Parsnip.}

IMPROVED GUERNSEY.-A greatly improved and wonderfully fine strain of Guernsey Parsnip, which we have sold largely to our customers, all of whom are unanimous in praising the fine quality. The ioots do not grow so long as the Hollow Crown, but are of greater diameter and more easily gathered. It is a very heavy cropper." "The roots are very smooth, the flesh is fine-grained and of most exceilent quality. Per pkt. 5 cts.

\section{Peas}

BURPEE'S EXTRA EARLI.-This is unsurpassed in extra earliness, productiveness, and freedom from runners. None ripen earlier, and few as early. Height about two feet, quality excellent, and the crop can be gathered in two pickings. A so for a late fall crop it is unsurpassed. growing with great rapidity. Market gardeners, this is your best Extra Early. In recommending this strain, we are fully acquainted with all existing varieties, and are quite sure that none, under whatever fancy name, "sealed bags." or otherwise. can surpass BurpeE's ExTRA EARLY. Per pkt. In cts.; pint 25 cts.; quart 45 cts., prepaid.

\section{Pepper.}

RED CHILI (True). Very small, bright red. cone-shaped, hot peppers; the best for pepper sauce. Per pkt. 5 cts.

\section{Radish.}

\section{FRENCH BREAKFAST. A new} quick-growing variety; oval form, color: 


\section{Squash}

HUBBARD. The best table squash yet known, good specimens being ahout equal in quality to the Sweet Potato. It has a hard shell, and with the same care will keep three months later than the Marrows. Per pkt. $5 \mathrm{cts}$.

BRAZIL SUGAR. This distinct, new variety for summer and autumn use is the richest flavored and sweetest of all squashes. It is liked for table use in every stage of its growth. During the months of August, September and October, it has no equal. It is enormously productive. A single plant has yielded as many as twelve perfectly ripened squashes. They weigh rim two to four pounds each ; measuring six to eightinchesin length and from tour to $\mathrm{ix}$ inches in thickness. The skin is a beautiful canary color, and generally handsomely warted. The flesh is also rellow, slightly tinged with green. The vines grow so rapidly that the are but little liable to injury from the striped bug. Per pkt. Io cts.

\section{Turnip.}

AMBER GLOBE. Oine of the best varieties for general crop. Flesh very firm and sweet, and keeps well until spring. Grows to a large size, and is excellent both for stock or table use. Per pkt. $5 \mathrm{c}$; Oz., IOC.

(RUTA BAGA.) Carter's Imperial. A purple-top, yellow variety, very productive; one of the very best for field-culture.

\section{Lettuce.}

BLACK-SEEDED TENNISBALL. The popular variety with Boston market-gardeners for suminer growing; fine heads, crisp and hardv; and the earliest of the heading varieties. Per pkt. 5 cts.

HANSON. Heads very large; hearts quickly, and stands the summer well; quality exceilent. Per pkt. 5 cts.

\section{Melon, (water).}

PHINNEY'S EARLY-This is early. The melons are of medium size, oblong shape, and very uniform. the skin being mottled, as shown in the illustration; Hesh red and sweet. It is hardy and vigorous in growth; very productive. This melon will grow, when all others fail; it is excellen $t$ in quality. Pkt. $5 \mathrm{c}$. ; oz. IOc.

MAMMOTH IRONCLAD. This watermelon has such decided points of superi-

ority that it will speedily become a popular favorite. Perfectly shaped, and handsomely striped skin; flesh mealy, but firm, with rich, sugary flavor. Per pkt. $5 \mathrm{c}$.

VICK'S EARLY. Of medium size, oblong and smooth; flesh bright pink, resembling the Southern varieties; solid and sweet; one of the best early sorts. Per pkt. 5c.

\section{Melon, (Musk).}

MONTREAL GREEN NUTMEGThis melon grows very large, very many of them weighing ${ }_{5} 5$ to 20 lbs. It is a sure heavy bearer, producing as many large melons as any variety does small ones. Vines are vigorous and always healthy. The quality is as sweet and delicious as the smallest Nutmeg melon. Extra selected seeds, pkt. IOc.; oz. ${ }_{5} \mathrm{c}$.

\section{Mustard.}

WHITE. Best for salad, or ordinary purposes. Per pkt. $5 \mathrm{c}$.

\section{Tomato.}

LIVINGSTON'S PERFECTION. It is blood-red in color, perfectly smooth: has very few seeds; the largest early sort known; ripens all over and through at the same time. Per pkt. 5 cts.

CANADA VICTOR. Very early, smooth, red variety; fine keeper; excellent flavor.

\section{SEND A POST-}

al card for a free sample copy of the oldest and best agricultural and family paper in New England: the New ENGI.and FarMer. Its Grange edition, OUr Graxge Homes is the only distinctly Grange paper in New England. Boston, Mass.

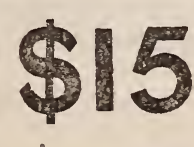

Send stamp for circulars. Address, Geo. R. Blakely, Bradford, McKean Co. Pa.

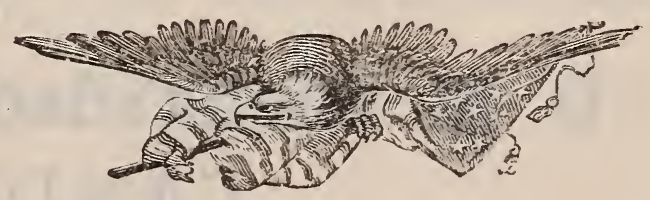

\section{For a Gold Filled Watch.}

Warranted to wear 15 years, with Elgin movement. 


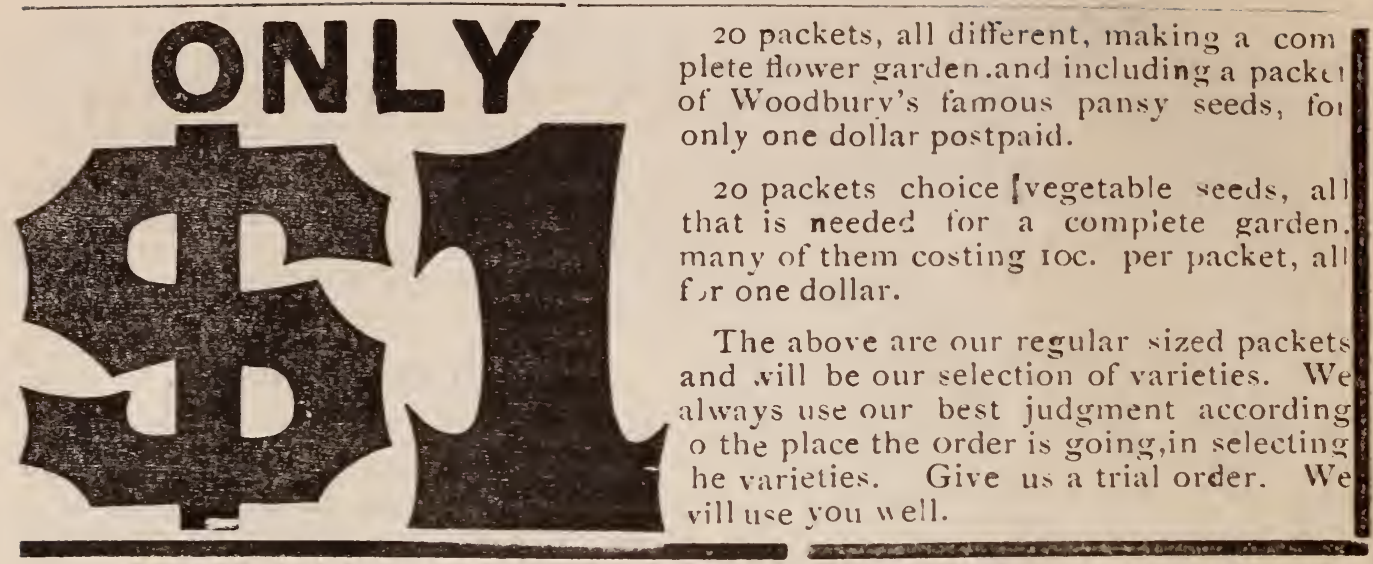

\section{Vegetable Plants.}

TOMATO, transplanted, 2 inches hig' 1 , 40 cts. per doz. \$2.50 per hundred.

CELERY, transplanted, stecky p'ants.

CABBAGE, nice thrifty plants. 10 cts. per doz. jo cts. per hundred.

I 5 cts. per doz., \$I.OO per hundred. ties $5 \mathrm{C}$. each, jo cts. perdoz.

\section{UNSOLICITED TESTIMONY}

Gorma.m, N. H., April, S, I8S9.

O. M. Richnrdson.Dear Sir:- My order of plants came all right and in a splendid condition. I am very much pleased with them. Thanks for the extra ones.

Mrs. C. E. Philbrook, Gorham, N. H.

The plants arrived all right and they are fine ones. The Mrs. Crawford Gerainum is worth the price I paid for all.

C. (j. Drake,

Pruvidence, R I.

I am delighted with $m y$ plants which I have iust received. Vany thanks for the

$$
\begin{array}{ll}
\text { extras. } & \text { E. E. KImBall, } \\
\text { N. E. Harbor, Me. }
\end{array}
$$

E. E. KIMBALL,

The plants you sent me are just splendid, and I now want some more.

Postmaster,

Eustis, Me. before.

The plants you sent me are large and are doing betier than any I ever received MrS. D. CLARK.

N. 11 .

The box containing plants came Friday night in fine condition, and I am more than pleased. Thanks for your liberality in sending such an amount.

\section{Mrs. C. M. Bisbee,}

West Sumner, Me.

Wilsox's Mills, July:9. iSSS.

Mr. O. M. Rachardson, Dear Sir:-I received my plants to-day and am more than pleased with them. They were just as fresh as though just taken up, with scarcely a leaf jammed. I don't see how you can afford to give so much for the money. Many than's for the extras. When I want more plants I shali send to you.

Yours truly, Mrs. John Olsox.

\section{M. Richardson \& Co., Florists, CANTON, ME.}




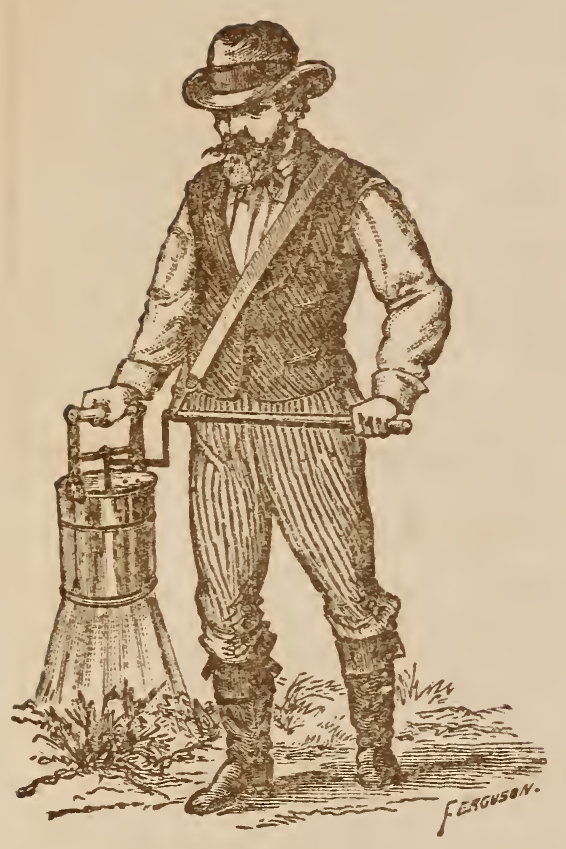

\section{The FRrmers' Favorite PuthTo Bur EXTERRINHTOR EDDY PATENT.}

The only prattical macidine for dusting Plaster. Palis (irentl. Plusphliates. etc

The simplest. wost durahle and hest conl. trirance ever used for the fumpere. It will do the nork effectualiy as fast an a perosm cul walk.

The quautity of plaster nsed. amr? slanes covered, can be rewulatad at Will to sult iuly size of plant.

Dor sale by all dealers in Seeds and Agricultural Implements.

\section{APPLE TREES! APPLE TREES!}

200.000 Apple trees. All gruwn in New England soil. None thriftie). None better. None that will transplant into orchards with as little lis, to the planter. Also a

\section{Full Lime of Other Nansisery Stools.}

Also THE GREEN MOUNTAIN GRAPE. The earliest and best Iet introfuced. It is especially adapted to be planted when the other sorts of gratpe fatil to ripen on account of early frosts. Also the

\section{Yale Strawberry,}

The best latest strawherry in cultivation.

Send for circulars giving full information. Address, STPHEN HOYT'S SONS, NEW CANAAN, CONN. 


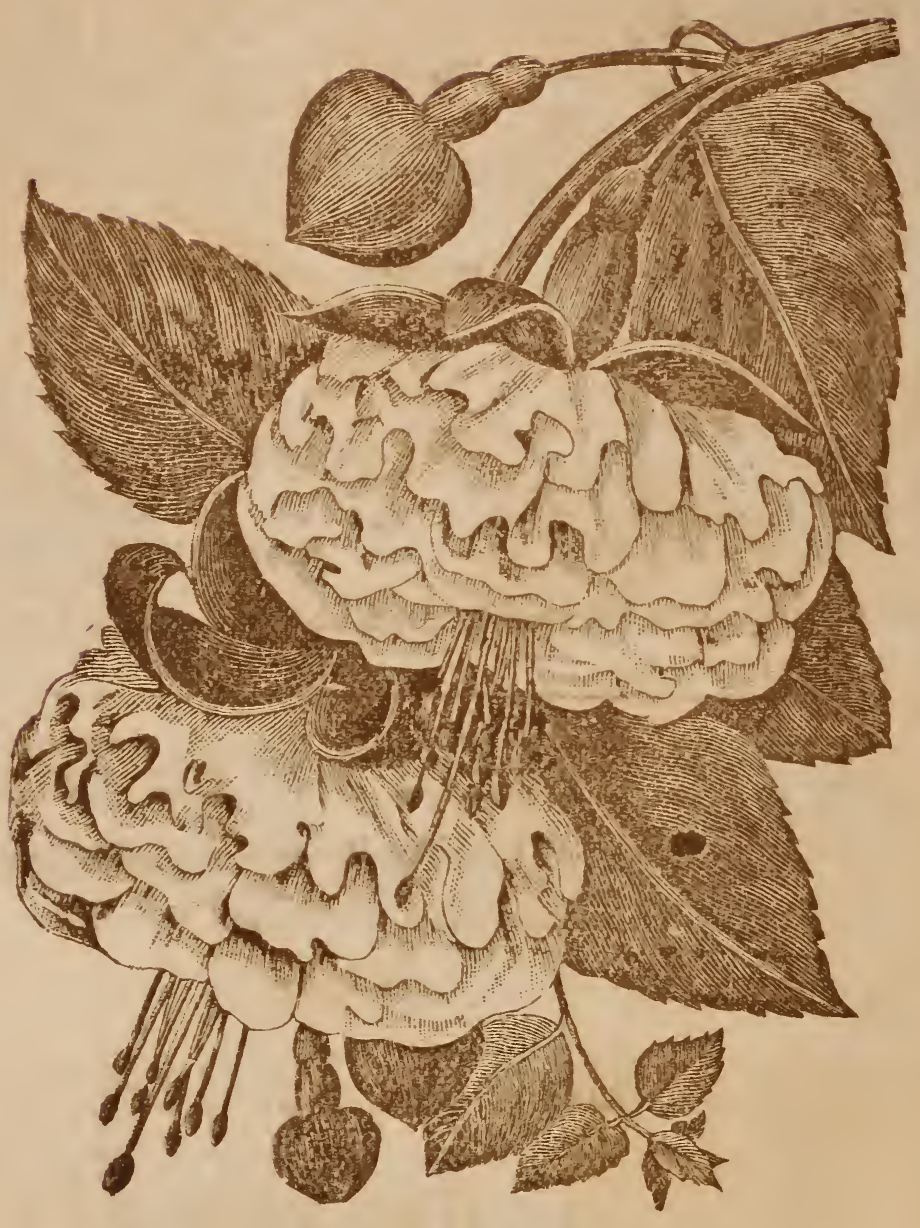

"In all places then, and in all seasons,

Flowers expand their bright and soul-lik: "'ings., leaching us by most persuasize reasons, llua akin they are to human things." 